\title{
ГЕОХИМИЧЕСКИЕ ОСОБЕННОСТИ И ИСТОЧНИКИ РАСПЛАВОВ НЕОАРХЕЙСКИХ УЛЬТРАКАЛИЕВЫХ РИОЛИТОВ КУРСКОГО БЛОКА ВОРОНЕЖСКОГО КРИСТАЛЛИЧЕСКОГО МАССИВА
}

\author{
Н. В. Холина \\ Воронежский государственный университет
}

Поступила в редакцию 16 января 2018 г.

\begin{abstract}
Аннотация: в пределах Курского блока Воронежского кристаллического массива располагаются неоархейские высококремнистые ультракалиевые риолиты, которые по своим геохимическим особенностям относятся к гранитоидам А-типа и сформировались во внутриплитной постколлизионной геодинамической обстановке. Формирование ультракалиевых расплавов кислого состава происходило при частичном высокотемпературном плавлении коры, которая обогащалась мантийным веществом, несущим калийсодержащие флюиды. В качестве корового источника расплава могли быть тоналит-трондьемит-гранодиоритовые гнейсы обоянского комплекса, а источником мантийного вещества в пределах Курского блока могут являться неоархейские метабазиты, подстилающие ультракалиевые риолиты.
\end{abstract}

Ключевые слова: неоархей, ультракалиевые риолиты, геохимия, Курский блок, гранитьл A-типа, источники расплавов.

\section{GEOCHEMICAL TYPIZATION AND SOURCES OF MELTS OF THE NEOARCHEAN ULTRA- POTASSIC RHYOLITES OF THE KURSK BLOCK, VORONEZH CRYSTALLINE MASSIF}

\begin{abstract}
Kursk Voronezh crystalline massif are Neoarchean high-ultrapotassic rhyolites, which by their geochemical characteristics belong to granitoids A-type and formed in intraplate post-collisional geodynamic setting. The formation of ultrapotassic melts acid composition occurred at high temperature partial melting crust, which has been enriched mantle substance bearing a potassiumcontaining fluids. As the crustal source of the melt could be tonalite-trondhjemite-granodiorite gneisses of the Oboyan complex and the source of the mantle material within the Kursk block can be Neoarchean metabasites, the underlying ultrapotassic rhyolites.
\end{abstract}

Keywords: Neoarchean, ultrapotassic rhyolites, geochemistry, Kursk block, A-type granites, sources of melts.

\section{Введение}

Риолиты с высоким содержанием калия достаточно широко развиты в различных регионах мира, где они образуются на завершающих стадиях орогенеза или при активизации платформ (континентальный рифтогенез). Появляясь на завершающих этапах орогенного развития регионов, а также в процессе их тектоно-магматической активизации. Ультракалиевые риолиты могут служить реперами тектонической стадийности, позволяющими проследить эволюцию вулканической деятельности во времени и в пространстве на различных этапах геотектонического развития регионов.

На территории Курского блока Воронежского кристаллического массива риолиты с высоким содержанием калия располагаются в пределах ВоронецкоАлексеевского зеленокаменного пояса и распространены ограниченно в южном замыкании ТимЯстребовской структуры (рис. 1). Неоархейские кис- лые вулканиты объединены в лебединскую свиту михайловской серии и стратиграфически залегают на границе неоархея и палеопротерозоя.

В настоящей статье задачами исследования являются: (1) выявление геохимических особенностей неоархейских ультракалиевых риолитов Курского блока, (2) установление источников расплавов и тектонической обстановки проявления кислого магматизма в конце неоархея.

\section{Геологическое положение}

Курский блок расположен в западной части Воронежского кристаллического массива и представляет собой гранит-зеленокаменную область, в пределах которой выделяются два неоархейских зеленокаменных пояса северо-западного простирания: западный Льговско-Ракитнянский (Белгородско-Михайловский) и восточный Алексеевско-Воронецкий (Орловско-Тимской). 


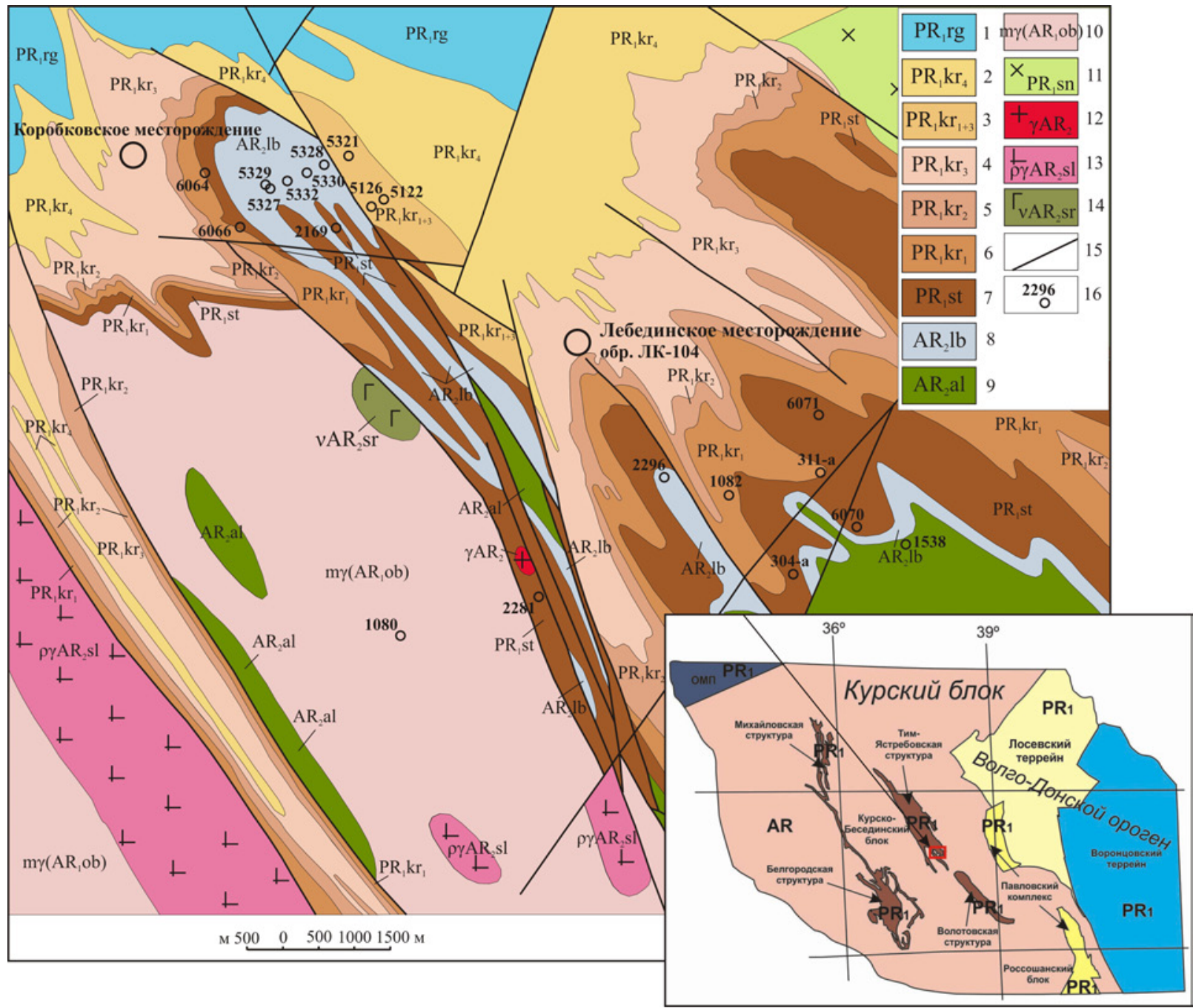

Puc. 1. Схематическая геологическая карта Старооскольского рудного района с расположением скважин, вскрывших лебединскую свиту михайловской серии (по неопубликованным материалам Н. А. Плаксенко). НИЖНИЙ ПРОТЕРОЗОЙ. Оскольская серия: 1 - роговская свита. Кварцево-слюдистые сланцы, известняки и доломиты, метаалевролиты, метапесчаники, конгломераты. Курская серия. 2-7: 2-6 - коробковская свита. Кварциты магнетитовые, магнетит-гематитовые, силикатно-магнетитовые; сланцы кварц-биотитовые, кварц-амфиболовые, кварц-хлоритовые, углеродистые. 7 - стойленская свита. Сланцы кварц-биотитовые, кварц-серицитовые, кварц-хлоритовые, кварц-двуслюдяные, метапесчаники, кварциты, метагравелиты, метаконгломераты. ВЕРХНИЙ АРХЕЙ. 8-9 - Михайловская серия: 8 - лебединская свита. Метариолиты, метариодациты, метадациты, сланцы кварц-биотитовые, кварц-двуслюдяные, кварц-хлоритовые, иногда метапесчаники, кварциты; 9 - александровская свита. Ортоамфиболиты, ортосланцы основного и ультраосновного состава. НИЖНИЙ AРХЕЙ. 10 - обоянская серия. Мигматизированные и гранитизированные гнейсы, мигматиты, прослои амфиболитов, амфиболовых сланцев. ИНТРУЗИВНЫЕ КОМПЛЕКСЫ. Раннепротерозойские: 11 - стойло-николаевский комплекс. Вторая фаза - гранодиориты, диориты, габбродиориты. 12-13 - позднеархейские: 12 - гранит-порфиры; 13 - салтыковский комплекс. Плагиограниты, тоналиты, гранодиориты; 14 - сергеевский комплекс. Вторая фаза - амфиболизированное габбро, аподиабазовые амфиболиты; 15 - региональные разломы; 16 - буровые скважины и их номера.

Ультракалиевые риолиты распространены локально в южном обрамлении Тим-Ястребовской структуры Алексеевско-Воронецкого зеленокаменного пояса, где они сохранились от размыва в отдельных структурно-фациальных зонах (Старооскольский рудный район) (рис. 1). Стратиграфическое положение пород установлено точно, так как в ряде скважин (6064, 6066, 5321, 12-а и др.) на толще вулканитов с размывом и угловым несогласием залегают метапесчаники и метаконгломераты стойленской свиты курской серии. Максимальная видимая мощность отложений до $300 \mathrm{M.}$
В разрезах скважин (5321, 5329 и др.) отмечены маломощные прослои метапесчаников, разделяющие толщу вулканических пород на отдельные пачки и фиксирующие прерывистый характер процесса вулканизма. Количество потоков в разрезах скважин установить трудно, на их наличие указывает только присутствие прослоев осадочных пород (рис. 2).

Абсолютный возраст, определенный U-Pb методом по циркону из ультракалиевых риолитов Лебединского участка (гидрогеологическая шахта под Лебединским железорудным карьером, обр. ЛК-104), составляет 2612 \pm 10 млн. лет (SHRIMP) [1]. 


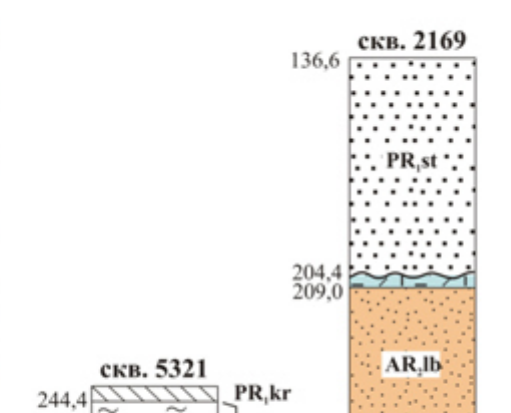

${ }_{176.6}$ скв. 228
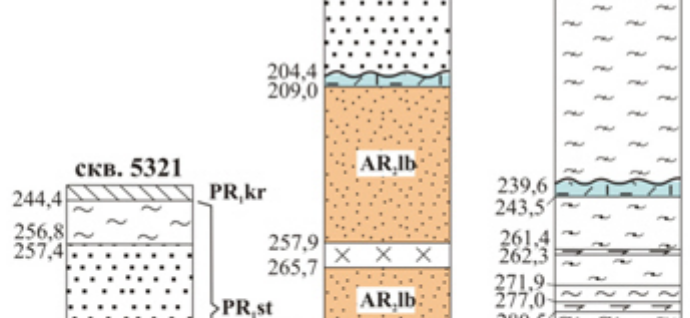

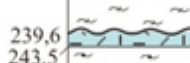
$261.4 \div 2$ $271,0 \approx \approx \sim \sim 7$ PR

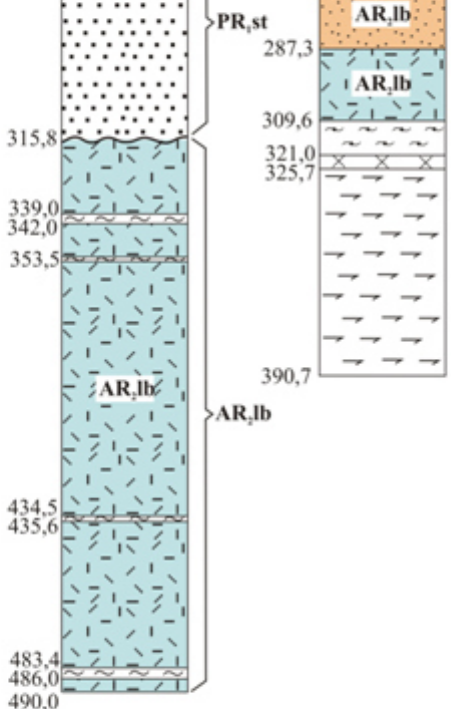

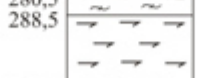

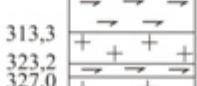
$224,0=0$

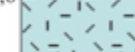

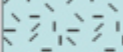

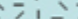
질 IAR, Ib

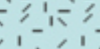
溥北

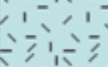

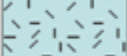
AR 1-

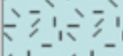

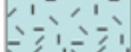

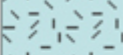
370,0 二况
$351,60,-1=0$

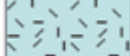

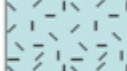

$\therefore \quad 1=$

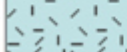

这

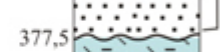

490.0

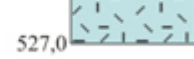

Puc. 2. Разрезы скважин, вскрывших образования неоархейских ультракалиевых риолитов КМА: 1 - кварцевый метапесчаник (PR $\mathrm{st}_{1}$; 2 - кварц-биотит-полевошпатовый месланцы биотит-полевошпатовые; 7 - сланцы биотит-амфиболовые; 8 - амфиболиты; 9 - диориты; 10 - сланцы и железистые кварциты курской серии (PR $\mathrm{kr}_{\text {) }}, 11$ - разломы. 


\section{Петрография}

Среди кислых эффузивов наибольшим распространением пользуются литокристаллокластические метатуфы риолитового состава (скв. 311a, 304a, 2296, 5328 и др.) и метариолиты (скв. 2296, 5327, 5328, 5329, 6066 и др.) (рис. 3). Все породы подверглись региональному метаморфизму, рассланцованы в различной степени, участками до мусковит-кварцевых сланцев.

Метатуфы риолитового состава и метариолиты макроскопически схожи, серой и светло-серой окраски иногда с розовым оттенком, сланцеватой текстуры, структура порфировидная, обусловленная наличием в мелкозернистой основной массе крупных зерен (кристаллокластов и порфировидных вкрапленников) кварца, микроклина. В метатуфах часто наблюдаются мелкие обломки кристаллических биотитовых сланцев, метапесчаников. Микроскопически породы характеризуются порфировой, порфиробластовой структурой с гранобластовой, лепидогранобластовой и микролепидогранобластовой структурами основной массы (рис. 3а, б, в, г). В риолитах отсутствует вулканическое стекло, которое было перекристаллизовано при метаморфических изменениях.

Вкрапленники составляют до 15 \% объема породы. Резко преобладающими являются вкрапленники кварца характерного бледно-голубого цвета (иногда

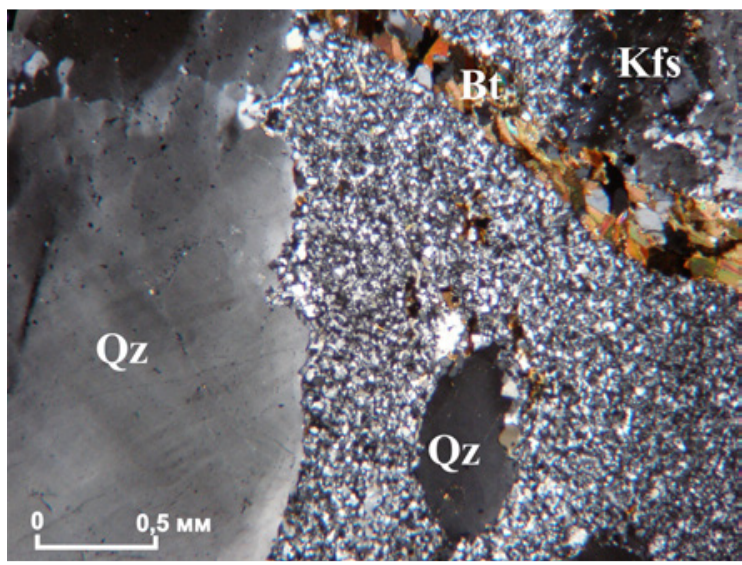

Puc. 3a. Метариолит. Николи скрещены, увеличение $\mathrm{x} 4$, обр. 2296/250,5.

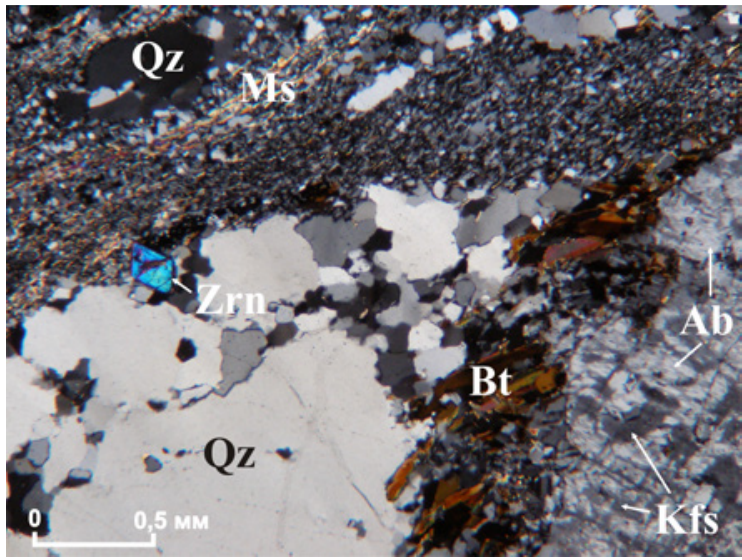

Рис. 3в. Метатуф риолитового состава. Николи скрещены, увеличение х4, обр. 5329/170,8. до 10 мас. \%). Их форма преимущественно угловатоокруглая, иногда наблюдаются кристаллы близкие к прямоугольной или шестиугольной форме размером до 5-7 мм. Присутствуют также вкрапленники микроклин-пертита, представляющие собой структуры распада, состоящие из альбита и микроклина, угловатоокруглой формы (рис. 3в). Отмечаются отдельные единичные зерна микроклина с хорошо выраженной решетчатой структурой размером от 0,5 до 3 мм.

Ориентировки распределения вкрапленников не наблюдается. Кроме вкрапленников присутствуют ксенокристаллы, образующие агрегаты мелких зерен. Ксенокристаллы кварца срастаются в отдельные участки или прерывистые полосы.

Основная масса породы представлена равномернозернистым агрегатом зерен кварца размером 0,05 мм и меньше, составляющим 55-60 \% объема породы, полевыми шпатами - альбитом и микроклином (около $15 \%$ ), мусковитом (до $15 \%$ ), биотитом до $5 \%$. Акцессорные минералы представлены редкоземельными фосфатами (монацит, ксенотим), силикатами (циркон, эпидот, алланит, цоизит), единичными зернами апатита, рутила. Рудные минералы представлены единичными зернами пирита (до $2 \%$ ), сфалерита (до $1 \%$ ), ильменита (около $1 \%$ ). В качестве вторичных минералов присутствуют бастнезит, хлорит, кальцит.

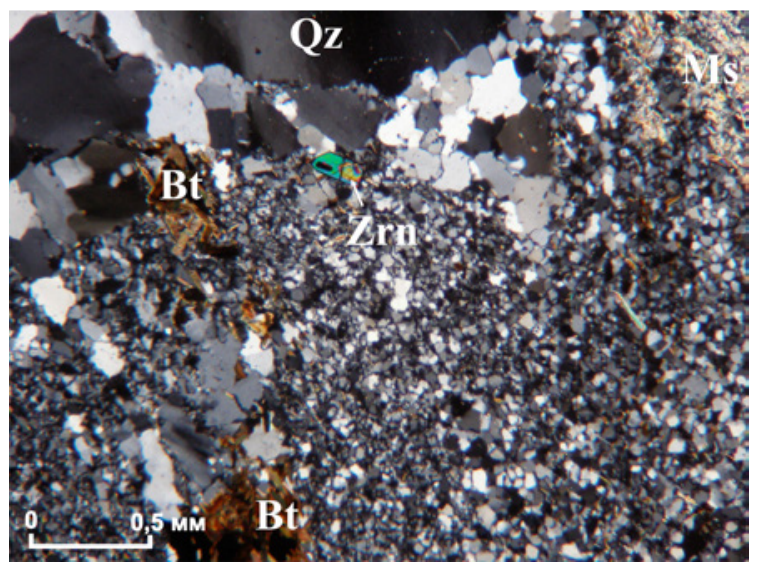

Рис. 3б. Метариолит. Николи скрещены, увеличение х4, обр. 2296/211,5.

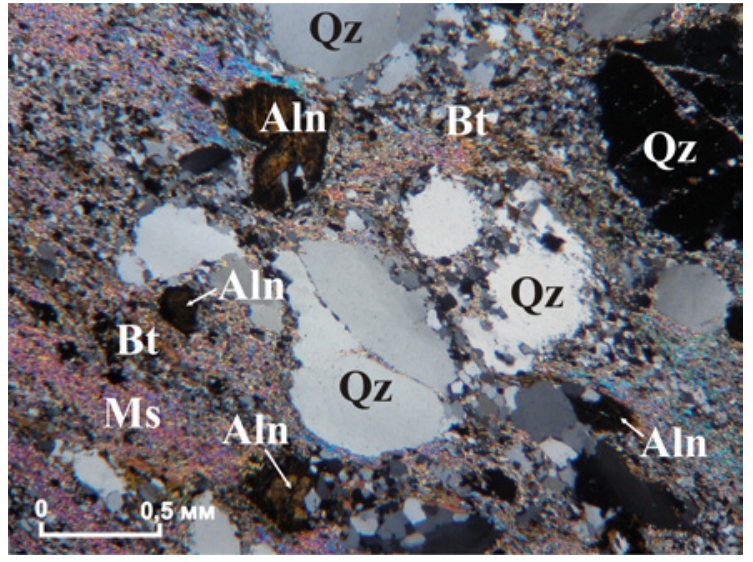

Рис. 32. Метатуф риолитового состава. Николи скрещены, увеличение х4, обр. 5328/297,7. 


\section{Методика аналитических исследований}

Анализы химического состава проб производили на спектрометре последовательного действия PW2400 производства компании PhilipsAnalytical B.V в ИГЕМ РАН. При калибровке спектрометра использованы отраслевые и государственные стандартные образцы химического состава горных пород и минерального сырья (14 ОСО, 56 ГСО). Подготовка препаратов для анализа породообразующих элементов выполнена путем плавления 0,3 г порошка пробы с 3 г тетрабората лития в индукционной печи с последующим отливом гомогенного стеклообразного диска. Точность анализа составляла 1-5 отн. \% для элементов с концентрациями выше 0,5 мас. \% и до 12 отн. \% для элементов с концентрацией ниже 0,5 мас. \%.

Малые и редкие элементы определяли методом индукционно-связанной плазмы с масс-спектрометрическим окончанием анализа (ICP-MS) в АСИЦ ИПТМ РАН. Разложение образцов пород, в зависимости от их состава, проводили путем кислотного вскрытия, как в открытой, так и в закрытой системах. Пределы обнаружения для REE, Hf, Ta, Th, U составляли 0,020,03 ppm, для $\mathrm{Nb}, \mathrm{Be}, \mathrm{Co}-0,03-0,05 \mathrm{ppm}$, для $\mathrm{Li}, \mathrm{Ni}$, $\mathrm{Ga}, \mathrm{Y}-0,1 \mathrm{ppm}$, для $\mathrm{Zr}-0,2 \mathrm{ppm}$, для $\mathrm{Rb}, \mathrm{Sr}, \mathrm{Ba}-0,3$ ppm, для $\mathrm{Cu}, \mathrm{Zn}, \mathrm{V}, \mathrm{Cr}-1-2$ ppm. Правильность анализа контролировалась путем измерения международных и российских стандартных образцов GSP-2, ВМ, СГД-1А, СТ-1. Ошибки определения концентраций составляли от 3 до 5 мас. \% для большинства элементов.

$\mathrm{Sm}-\mathrm{Nd}$ изотопный анализ и изотопные исследования цирконов выполнены в Центре изотопных иссле- дований ВСЕГЕИ (Санкт-Петербург). Выделение циркона проводилось по стандартной методике с использованием тяжелых жидкостей. Измерения абсолютного возраста цирконов проводились на ионном микрозонде SHRIMP-II по стандартной методике [2] с использованием эталонных цирконов «91500» и «Temora». При расчетах использовали константы распада, предложенные в работе [3] и вводили поправку на нерадиогенный свинец по [4] на основе измеренного отношения ${ }^{204} \mathrm{~Pb} /{ }^{206} \mathrm{~Pb}$. Полученные результаты обрабатывали с помощью программ «SQUID v1.12» и «ISOPLOT/Ex 3.22» [5, 6].

\section{Петрогеохимия}

Метариолиты и метатуфы риолитового состава характеризуются высокими содержаниями $\mathrm{SiO}_{2}$, часто превышающими 75 мас. \% (табл. 1, рис. 4a), высоким содержанием $\mathrm{K}_{2} \mathrm{O}$ (до 7-8 \%) (рис. 5), низкими $\mathrm{CaO}$ $(0,05-1,4$ мас. \%) и $\mathrm{MgO}(0,34-1,4$ мас. \%), повышенной железистостью $(\mathrm{XFe}=0,54-0,89)$ и насыщенностью глиноземом (A/CNK = 1,05-2,0) (рис. 4б) [7]. В них отмечаются широкие вариации в целом повышенных содержаний щелочей $\left(\mathrm{K}_{2} \mathrm{O}+\mathrm{Na}_{2} \mathrm{O}=5,8-9,5\right)$ с преобладанием калия, часто очень резким $\left(\mathrm{K}_{2} \mathrm{O} / \mathrm{Na}_{2} \mathrm{O}\right.$ $=1,4-43,6)$ (табл. 1).

Зависимость содержаний петрогенных оксидов от концентрации $\mathrm{SiO}_{2}$ представлена на рис. 5 [8] и проявлена весьма незначительно. Это говорит о практически полном отсутствии линейности в изменении состава пород. Следовательно, породы представляют собой недифференцированную серию ультракалиевых риолитов.

Таблица 1

Химические составы неоархейских ультракалиевых риолитов лебединской свиты Курского блока

\begin{tabular}{|c|c|c|c|c|c|c|c|c|c|c|c|c|}
\hline Скв./глуб. & $\begin{array}{l}2296 / \\
211,5\end{array}$ & $\begin{array}{l}2296 / \\
250,5\end{array}$ & $\begin{array}{l}2296 / \\
260,3\end{array}$ & $\begin{array}{l}2296 / \\
288,5\end{array}$ & $\begin{array}{l}2296 / \\
297,8\end{array}$ & $\begin{array}{l}2296 / \\
324,0\end{array}$ & $\begin{array}{l}5329 / \\
170,8\end{array}$ & $\begin{array}{l}5329 / \\
203,7\end{array}$ & $\begin{array}{l}5329 / \\
228,0\end{array}$ & $\begin{array}{l}5329 / \\
238,2\end{array}$ & $\begin{array}{l}5329 / \\
386,6\end{array}$ & $\begin{array}{l}5329 / \\
391,8\end{array}$ \\
\hline $\mathrm{SiO}_{2}$ & 76,65 & 75,2 & 74,5 & 72,3 & 75,8 & 75,17 & 74,5 & 73,98 & 72,04 & 74,17 & 76,56 & 76,2 \\
\hline $\mathrm{TiO}_{2}$ & 0,28 & 0,4 & 0,41 & 0,39 & 0,37 & 0,23 & 0,46 & 0,33 & 0,34 & 0,35 & 0,16 & 0,28 \\
\hline $\mathrm{Al}_{2} \mathrm{O}_{3}$ & 10,5 & 12,2 & 13,0 & 13,9 & 10,85 & 11,59 & 12,35 & 12,06 & 13,66 & 13,03 & 12,34 & 12,7 \\
\hline $\mathrm{FeO}$ & н.п. & 1,97 & 1,44 & 2,63 & 2,27 & н.П. & 1,8 & н.П. & 0,84 & н.п. & н.П. & 1,02 \\
\hline $\mathrm{Fe}_{2} \mathrm{O}_{3}$ & 2,44 & 0,81 & 1,34 & 1,75 & 0,84 & 2,21 & 0,99 & 2,9 & 1,97 & 2,63 & 0,63 & 0,79 \\
\hline $\mathrm{MgO}$ & 0,49 & 0,48 & 0,72 & 0,76 & 0,76 & 0,48 & 0,51 & 0,34 & 0,59 & 0,48 & 0,34 & 0,63 \\
\hline $\mathrm{MnO}$ & 0,015 & 0,03 & 0,02 & 0,04 & 0,02 & 0,026 & 0,03 & 0,023 & 0,073 & 0,025 & 0,01 & $<0,01$ \\
\hline $\mathrm{CaO}$ & 0,057 & 0,44 & 0,33 & 0,72 & 0,44 & 0,53 & 0,33 & 0,27 & 1,3 & 0,18 & 0,15 & 0,22 \\
\hline $\mathrm{Na}_{2} \mathrm{O}$ & 0,63 & 1,52 & 0,25 & 0,13 & 1,76 & 3,75 & 1,69 & 3,74 & 3,02 & 2,72 & 1,28 & 0,72 \\
\hline $\mathrm{K}_{2} \mathrm{O}$ & 8,06 & 6,73 & 6,51 & 5,68 & 6,09 & 5,33 & 4,86 & 5,71 & 5,14 & 5,36 & 7,72 & 6,12 \\
\hline $\mathrm{P}_{2} \mathrm{O}_{5}$ & 0,034 & 0,06 & 0,06 & 0,06 & 0,04 & 0,037 & 0,06 & 0,035 & 0,02 & 0,04 & 0,018 & 0,03 \\
\hline ППП & 0,32 & 0,54 & 1,18 & 1,91 & 0,58 & 0,27 & 0,92 & 0,31 & 1,03 & 0,71 & 0,35 & 1,41 \\
\hline Сумма & 99,56 & 100,3 & 99,77 & 100,2 & 99,84 & 99,78 & 100,6 & 99,74 & 99,64 & 99,7 & 99,68 & 100,1 \\
\hline $\mathrm{Mg} \#$ & 0,19 & 0,15 & 0,21 & 0,15 & 0,2 & 0,19 & 0,16 & 0,12 & 0,2 & 0,17 & 0,37 & 0,26 \\
\hline Fe\# & 0,83 & 0,84 & 0,78 & 0,84 & 0,79 & 0,82 & 0,84 & 0,89 & 0,79 & 0,84 & 0,65 & 0,73 \\
\hline $\mathrm{K}_{2} \mathrm{O} / \mathrm{Na}_{2} \mathrm{O}$ & 12,81 & 4,42 & 26,04 & 43,69 & 3,46 & 1,42 & 2,87 & 1,52 & 1,7 & 1,97 & 6,0 & 8,5 \\
\hline $\mathrm{Na}_{2} \mathrm{O} / \mathrm{K}_{2} \mathrm{O}$ & 0,078 & 0,22 & 0,04 & 0,023 & 0,29 & 0,7 & 0,34 & 0,65 & 0,58 & 0,5 & 0,16 & 0,12 \\
\hline $\begin{array}{l}\mathrm{Fe}_{2} \mathrm{O}_{3}+\mathrm{MgO} \\
+\mathrm{MnO}+\mathrm{TiO}_{2}\end{array}$ & 3,225 & 3,65 & 2,49 & 5,57 & 1,99 & 2,95 & 3,79 & 3,6 & 3,39 & 3,48 & 1,15 & 1,70 \\
\hline $\mathrm{A} / \mathrm{CNK}$ & 1,2 & 1,4 & 1,61 & 2,13 & 1,05 & 1,2 & 1,79 & 1,24 & 1,44 & 1,57 & 1,35 & 1,54 \\
\hline
\end{tabular}


Геохимические особенности и источники расплавов неоархейских ультракалиевых риолитов ...

Продолжение табл. 1

\begin{tabular}{|c|c|c|c|c|c|c|c|c|c|c|c|c|}
\hline Скв./глуб. & $\begin{array}{l}\text { ЛК- } \\
104\end{array}$ & $\begin{array}{l}6066 / \\
505,5\end{array}$ & $\begin{array}{l}6072 / \\
351,0\end{array}$ & $\begin{array}{l}5328 / \\
217,8\end{array}$ & $\begin{array}{l}5327 / \\
310,7\end{array}$ & $\begin{array}{l}5321 / \\
339,8\end{array}$ & $\begin{array}{l}5321 / \\
376,0\end{array}$ & $\begin{array}{l}5321 / \\
394,4\end{array}$ & $\begin{array}{l}5321 / \\
473,8\end{array}$ & $\begin{array}{l}5321 / \\
487,5\end{array}$ & $\begin{array}{l}2281 / \\
322,4\end{array}$ & $\begin{array}{l}2281 / \\
367,0\end{array}$ \\
\hline $\mathrm{SiO}_{2}$ & 75,59 & 76,25 & 74,14 & 77,36 & 77,50 & 76,9 & 76,6 & 74,2 & 76,6 & 76,4 & 76,0 & 76,2 \\
\hline $\mathrm{TiO}_{2}$ & 0,19 & 0,24 & 0,43 & 0,16 & 0,25 & 0,2 & 0,18 & 0,27 & 0,21 & 0,2 & 0,25 & 0,18 \\
\hline $\mathrm{Al}_{2} \mathrm{O}_{3}$ & 13,20 & 11,38 & 10,76 & 11,8 & 13,3 & 11,8 & 11,8 & 12,0 & 11,7 & 11,9 & 12,45 & 12,55 \\
\hline $\mathrm{FeO}$ & Н.П. & Н.П. & 2,46 & н.п. & 1,2 & 1,2 & 1,56 & 1,62 & 1,08 & 1,44 & 1,08 & 0,6 \\
\hline $\mathrm{Fe}_{2} \mathrm{O}_{3}$ & 1,24 & 2,26 & 3,28 & 1,51 & 0,39 & 0,69 & 0,77 & 1,12 & 1,5 & 0,62 & 0,82 & 0,72 \\
\hline $\mathrm{MgO}$ & 1,04 & 0,43 & 1,28 & 0,76 & 0,49 & 0,87 & 1,42 & 1,86 & 1,02 & 0,71 & 0,86 & 0,47 \\
\hline $\mathrm{MnO}$ & 0,005 & 0,02 & 0,06 & Н.П. & 0,04 & 0,03 & 0,04 & 0,04 & 0,03 & 0,04 & 0,02 & 0,01 \\
\hline $\mathrm{CaO}$ & 0,05 & 0,38 & 1,4 & н.п. & 0,37 & 0,12 & 0,37 & 0,18 & 0,25 & 0,37 & 0,66 & 0,44 \\
\hline $\mathrm{Na}_{2} \mathrm{O}$ & 0,21 & 2,15 & 1,0 & 0,78 & 1,41 & 0,35 & 0,66 & 1,28 & 0,36 & 0,26 & 2,72 & 2,93 \\
\hline $\mathrm{K}_{2} \mathrm{O}$ & 6,43 & 4,40 & 4,7 & 7,22 & 5,67 & 5,72 & 5,83 & 5,77 & 5,62 & 6,48 & 4,22 & 4,81 \\
\hline $\mathrm{P}_{2} \mathrm{O}_{5}$ & 0,02 & 0,02 & 0,05 & н.п. & 0,03 & 0,02 & $<0,02$ & 0,02 & 0,02 & 0,02 & $<0,03$ & $<0,03$ \\
\hline ППП & 1,85 & 1,31 & 1,32 & 0,24 & 1,14 & 1,28 & 1,15 & 0,97 & 1,35 & 1,15 & 0,69 & 0,48 \\
\hline Сумма & 99,85 & 99,89 & 98,42 & 99,87 & 99,49 & 99,18 & 100,4 & 99,34 & 99,75 & 99,64 & 99,77 & 99,39 \\
\hline $\mathrm{Mg} \#$ & 0,48 & 0,16 & 0,19 & 0,33 & 0,24 & 0,32 & 0,38 & 0,41 & 0,29 & 0,26 & 0,32 & 0,27 \\
\hline Fe\# & 0,54 & 0,84 & 0,80 & 0,66 & 0,76 & 0,67 & 0,61 & 0,58 & 0,70 & 0,73 & 0,68 & 0,72 \\
\hline $\mathrm{K}_{2} \mathrm{O} / \mathrm{Na}_{2} \mathrm{O}$ & 30,62 & 2,04 & 4,7 & 9,21 & 4,02 & 16,3 & 8,83 & 4,5 & 15,6 & 24,9 & 1,55 & 1,64 \\
\hline $\mathrm{Na}_{2} \mathrm{O} / \mathrm{K}_{2} \mathrm{O}$ & 0,032 & 0,48 & 0,21 & 0,1 & 0,25 & 0,06 & 0,11 & 0,22 & 0,06 & 0,04 & 0,64 & 0,6 \\
\hline $\begin{array}{l}\mathrm{Fe}_{2} \mathrm{O}_{3}+\mathrm{MgO} \\
+\mathrm{MnO}+\mathrm{TiO}_{2} \\
\end{array}$ & 2,47 & 2,95 & 5,05 & 2,43 & 1,17 & 1,79 & 2,41 & 3,29 & 2,76 & 1,57 & 1,09 & 1,38 \\
\hline $\mathrm{A} / \mathrm{CNK}$ & 1,97 & 1,26 & 1,51 & 1,47 & 1,45 & 1,69 & 1,46 & 1,38 & 1,64 & 1,46 & 1,21 & 1,16 \\
\hline
\end{tabular}

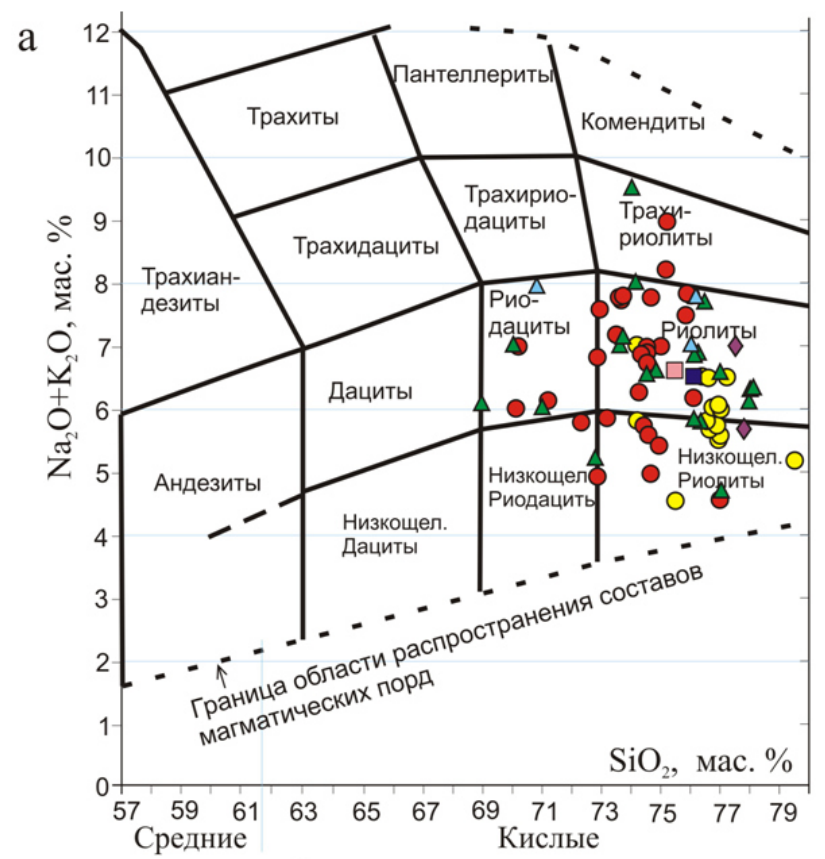
$\square$ - обр. ЛК-104
๘ - скв. 6066
- - скв. 2296
О - скв. 5321
$\Delta$ - скв. 5329
$\triangle$ - скв. 2281
$\checkmark$ - скв. 5327

Рuc. 4. Положение точек составов неоархейских ультракалиевых риолитов лебединской свиты Курского блока на классификационных петрохимических диаграммах: $a-\mathrm{SiO}_{2}-\left(\mathrm{Na}_{2} \mathrm{O}+\mathrm{K}_{2} \mathrm{O}\right) ; \sigma-\mathrm{A} / \mathrm{NK}-\mathrm{A} / \mathrm{CNK}$ [7], где $\mathrm{A}=\mathrm{Al}_{2} \mathrm{O}_{3}$, $\mathrm{N}=\mathrm{Na}_{2} \mathrm{O}, \mathrm{K}=\mathrm{K}_{2} \mathrm{O}, \mathrm{C}=\mathrm{CaO}$ (в молекулярных количествах).

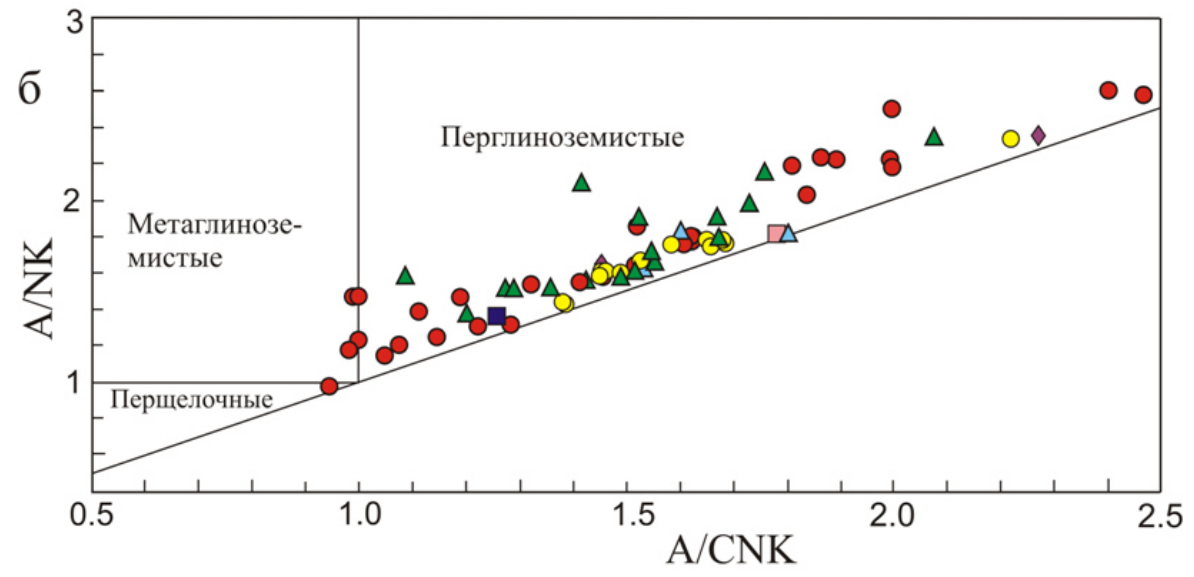




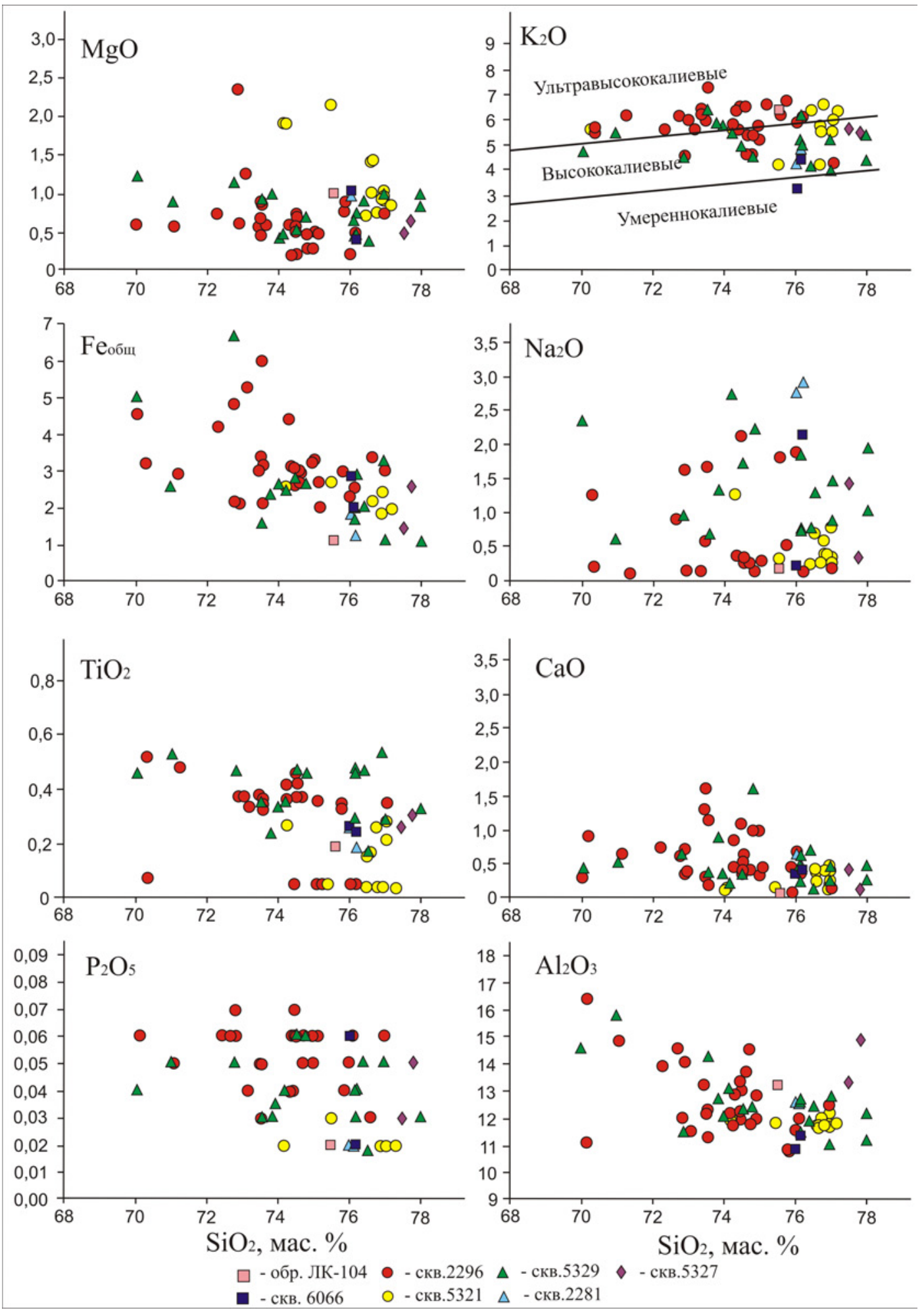

Puc. 5. Положение фигуративных точек составов неоархейских ультракалиевых риолитов лебединской свиты Курского блока на вариационных диаграммах Харкера [8].

По содержанию редких и редкоземельных элементов ультракалиевые риолиты резко обеднены $\mathrm{Sr}(20$ $60 \mathrm{ppm})$, обогащены Ва (до более чем $1000 \mathrm{ppm}), \mathrm{Rb}$ (116-208 ppm), высокозарядными элементами, особенно $\mathrm{Nb}$ (22-75 ppm), Та (1,6-3,7 ppm), Y (43-90 ppm), Th (16-29 ppm), и редкоземельными элементами $(\mathrm{REE})\left(\sum \mathrm{REE}=413-683 \mathrm{ppm}\right)$ (табл. 2, рис. 6). В распределении REE отмечается обогащение легкими редкоземельными элементами с сильным фракционированием $(\mathrm{La} / \mathrm{Yb})_{\mathrm{n}}=9,5-16$ и глубокими отрицательными европиевыми аномалиями $\mathrm{Eu} / \mathrm{Eu}^{*}=0,10-0,39$. Тяжелые редкоземельные элементы (HREE) характеризуются относительно «плоским» распределением $\left(\mathrm{Gd} / \mathrm{Yb}_{\mathrm{N}}=1,5-2,2\right)$.

ВЕСТНИК ВГУ. СЕРИЯ: ГЕОЛОГИЯ. 2018. № 1 
Геохимические особенности и источники расплавов неоархейских ультракалиевых риолитов ...

Таблица 2

Содержания редких и редкоземельных элементов в неоархейских ультракалиевых риолитах лебединской свиты Курского блока

\begin{tabular}{|c|c|c|c|c|c|c|c|}
\hline Скв./глуб. & $2296 / 211,5$ & $2296 / 324,0$ & ЛК-104 & $5329 / 203,7$ & $5329 / 228,0$ & $5329 / 238,2$ & $5329 / 386,6$ \\
\hline $\mathrm{Li}$ & 6,9 & 10,8 & 19,6 & 11,1 & 12,2 & 14,1 & 11,2 \\
\hline $\mathrm{Be}$ & 1,1 & 5,0 & 2,9 & 1,3 & 2,3 & 2,2 & 5,1 \\
\hline $\mathrm{Sc}$ & 3,1 & 3,0 & 2,5 & 3,0 & 3,7 & 2,6 & 0,58 \\
\hline $\mathrm{V}$ & 17,7 & 19,8 & 9,2 & 26,5 & 9,6 & 7,9 & 16,6 \\
\hline $\mathrm{Cr}$ & 14,1 & 13,5 & 0,64 & 25,4 & 1,9 & 1,2 & 18,1 \\
\hline $\mathrm{Co}$ & 1,2 & 1,5 & 0,51 & 0,80 & 0,94 & 0,47 & 1,7 \\
\hline $\mathrm{Ni}$ & 0,87 & $<$ ८ & 0,85 & 0,69 & 2,2 & 0,82 & 1,2 \\
\hline $\mathrm{Cu}$ & 54,9 & 6,9 & 3,9 & 4,2 & 4,8 & 3,3 & 8,3 \\
\hline $\mathrm{Zn}$ & 1301 & 64,5 & 17,7 & 64,8 & 90,2 & 80,1 & 434 \\
\hline $\mathrm{Ga}$ & 14,0 & 15,0 & 18,9 & 17,6 & 22,7 & 21,5 & 18,0 \\
\hline $\mathrm{Rb}$ & 154 & 116 & 155 & 118 & 122 & 146 & 208 \\
\hline $\mathrm{Sr}$ & 200 & 48,7 & 45,4 & 20,1 & 58,8 & 36,7 & 22,0 \\
\hline $\mathrm{Y}$ & 62,4 & 43,2 & 50,6 & 60,5 & 80,2 & 80,9 & 89,5 \\
\hline $\mathrm{Zr}$ & 431 & 449 & 243 & 559 & 601 & 454 & 560 \\
\hline $\mathrm{Nb}$ & 29,3 & 36,2 & 21,6 & 60,1 & 51,9 & 50,1 & 75,0 \\
\hline Mo & 1,9 & 1,6 & 0,40 & 0,64 & 0,91 & 0,39 & 4,2 \\
\hline $\mathrm{Cs}$ & 1,6 & 0,86 & 1,8 & 0,96 & 1,2 & 1,4 & 0,84 \\
\hline $\mathrm{Ba}$ & 1365 & 1113 & 415 & 1076 & 1131 & 949 & 718 \\
\hline $\mathrm{La}$ & 92,0 & 97,3 & 92,4 & 115 & 134 & 146 & 155 \\
\hline $\mathrm{Ce}$ & 179 & 188 & 191 & 223 & 274 & 293 & 299 \\
\hline $\operatorname{Pr}$ & 19,7 & 20,6 & 19,1 & 24,1 & 30,2 & 32,2 & 32,5 \\
\hline $\mathrm{Nd}$ & 73,3 & 75,7 & 63,1 & 91,7 & 100 & 106 & 119,7 \\
\hline $\mathrm{Sm}$ & 12,3 & 12,7 & 11,6 & 15,4 & 17,8 & 18,6 & 20,8 \\
\hline $\mathrm{Eu}$ & 1,1 & 1,3 & 0,58 & 1,6 & 1,6 & 1,7 & 0,67 \\
\hline $\mathrm{Gd}$ & 10,9 & 10,7 & 10,2 & 12,5 & 16,7 & 16,7 & 17,9 \\
\hline $\mathrm{Tb}$ & 1,7 & 1,4 & 1,6 & 1,8 & 2,6 & 2,6 & 2,7 \\
\hline Dy & 10,4 & 7,7 & 9,0 & 10,6 & 14,6 & 14,3 & 15,5 \\
\hline Ho & 2,0 & 1,4 & 1,8 & 2,0 & 2,9 & 2,8 & 2,9 \\
\hline $\mathrm{Er}$ & 5,9 & 4,2 & 5,4 & 5,9 & 8,3 & 7,9 & 8,1 \\
\hline $\mathrm{Tm}$ & 0,80 & 0,58 & 0,78 & 0,81 & 1,2 & 1,1 & 1,0 \\
\hline $\mathrm{Yb}$ & 5,3 & 4,1 & 5,2 & 5,5 & 7,8 & 6,9 & 6,7 \\
\hline $\mathrm{Lu}$ & 0,72 & 0,59 & 0,75 & 0,78 & 1,16 & 0,99 & 0,88 \\
\hline Hf & 8,6 & 8,7 & 7,4 & 11,3 & 15,2 & 11,6 & 14,2 \\
\hline $\mathrm{Ta}$ & 1,6 & 1,6 & 1,6 & 2,7 & 3,1 & 2,8 & 3,7 \\
\hline $\mathrm{W}$ & 0,78 & 0,73 & 1,6 & 0,78 & 0,48 & 1,3 & 1,1 \\
\hline $\mathrm{Pb}$ & 209 & 28,8 & 8,1 & 4,1 & 18,5 & 5,7 & 67,0 \\
\hline $\mathrm{Bi}$ & 0,13 & $<\Pi О$ & 0,056 & $<\Pi О$ & 0,024 & 0,005 & $<\Pi О$ \\
\hline $\mathrm{Th}$ & 18,1 & 22,9 & 29,3 & 16,3 & 21,9 & 19,3 & 25,6 \\
\hline $\mathrm{U}$ & 3,1 & 2,8 & 4,6 & 2,1 & 2,6 & 2,2 & 5,0 \\
\hline$\sum$ REE & 415 & 426,9 & 412,5 & 510 & 612,8 & 650,8 & 683,3 \\
\hline $\mathrm{Eu} / \mathrm{Eu}^{*}$ & 0,29 & 0,39 & 0,16 & 0,34 & 0,28 & 0,29 & 0,1 \\
\hline$(\mathrm{Gd} / \mathrm{Yb}) \mathrm{n}$ & 1,64 & 2,11 & 1,58 & 1,82 & 1,72 & 1,95 & 2,15 \\
\hline$(\mathrm{La} / \mathrm{Yb}) \mathrm{n}$ & 11,64 & 16,05 & 11,98 & 14,02 & 11,58 & 14,26 & 15,49 \\
\hline $\mathrm{Sr} / \mathrm{Y}$ & 3,2 & 1,13 & 0,89 & 0,33 & 0,73 & 0,45 & 0,24 \\
\hline $\mathrm{La} / \mathrm{Yb}$ & 17,26 & 23,8 & 17,77 & 20,8 & 17,18 & 21,16 & 22,98 \\
\hline Ybn & 25,5 & 19,56 & 24,8 & 26,5 & 37,3 & 33,0 & 13,22 \\
\hline $\mathrm{Nb} / \mathrm{Ta}$ & 18,7 & 22,91 & 13,5 & 22,62 & 16,74 & 17,89 & 20,26 \\
\hline $\mathrm{Yb} / \mathrm{Ta}$ & 3,40 & 2,58 & 3,25 & 2,08 & 2,51 & 2,46 & 1,82 \\
\hline $\mathrm{Y} / \mathrm{Nb}$ & 2,13 & 1,19 & 2,34 & 1,01 & 1,54 & 1,61 & 1,19 \\
\hline $\mathrm{K} / \mathrm{Rb}$ & 216,42 & 286,08 & 214,7 & 281,39 & 272,62 & 227,39 & 159,9 \\
\hline
\end{tabular}




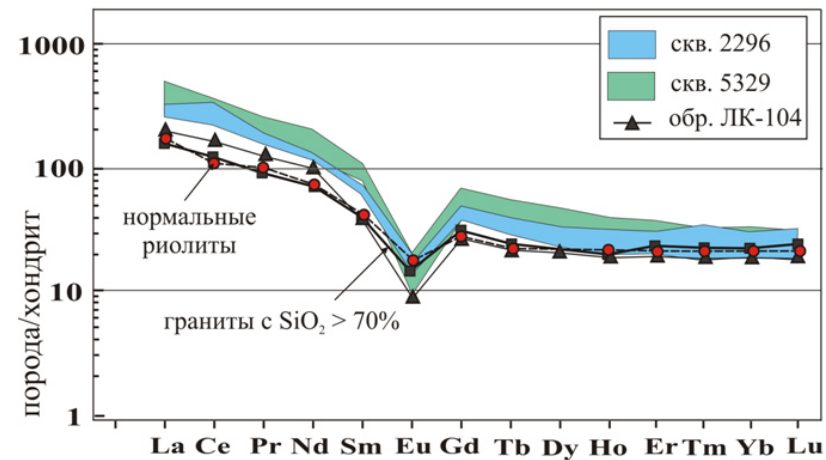

Рис. 6. Нормированные к хондриту содержания редкоземельных элементов в неоархейских ультракалиевых риолитах лебединской свиты Курского блока.

\section{Обсуждение результатов}

Геохимическая типизация кисльх вулканитов

Вулканиты кислого состава являются аналогами гранитоидов, поэтому для определения источников вулканитов могут быть использованы методики, при- меняемые для реконструкции источников гранитов.

Петрохимические особенности ультракалиевых риолитов, такие как: высокое содержание щелочей $\left(\mathrm{Na}_{2} \mathrm{O}+\mathrm{K}_{2} \mathrm{O}\right)$, низкие концентрации $\mathrm{CaO}$, а также обогащение $\mathrm{Ga}, \mathrm{Zr}, \mathrm{Nb}, \mathrm{Y}, \mathrm{REE}$ (кроме $\mathrm{Eu}$ ) и невысокие содержания $\mathrm{Sr}, \mathrm{Sc}, \mathrm{V}$ и $\mathrm{Eu}$ свидетельствуют о том, что кислые вулканиты близки к анарогенным гранитоидам А-типа. Это подтверждается положением точек их составов на дискриминантных диаграммах по [9] (рис. 7).

Определение геотектонической обстановки формирования риолитов по соотношениям редких элементов [10] показывает их образование во внутриплитных, либо постколлизионных условиях (рис. 8а). Совмещение полей двух обстановок не позволяет однозначно говорить о геодинамических условиях формирования кислых пород, поэтому была дополнительно использована серия дискриминантных диаграмм [11], на которых точки составов риолитов попадают в поле внутриплитной обстановки и имеют постколлизионную природу (рис. 8б).
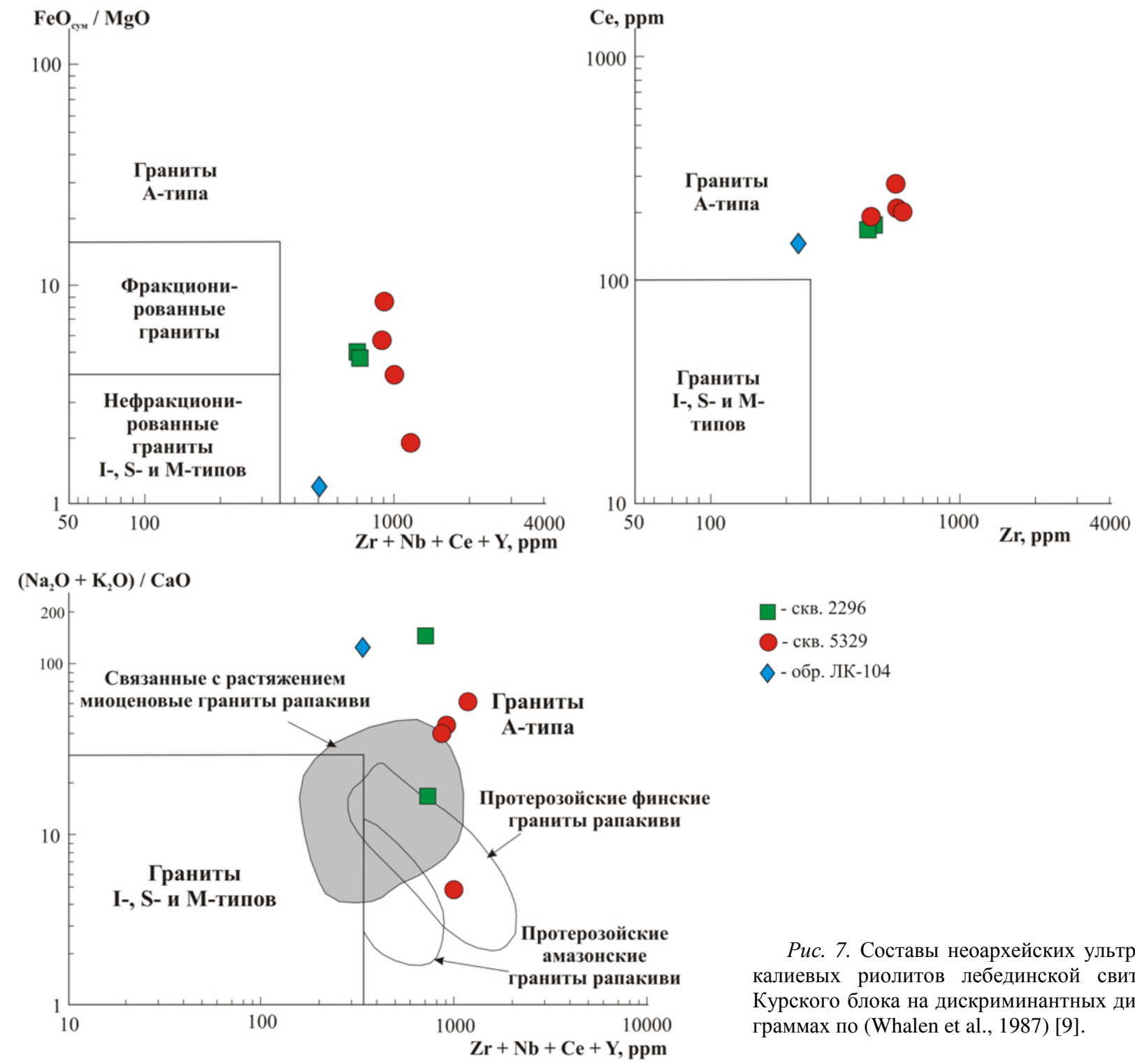

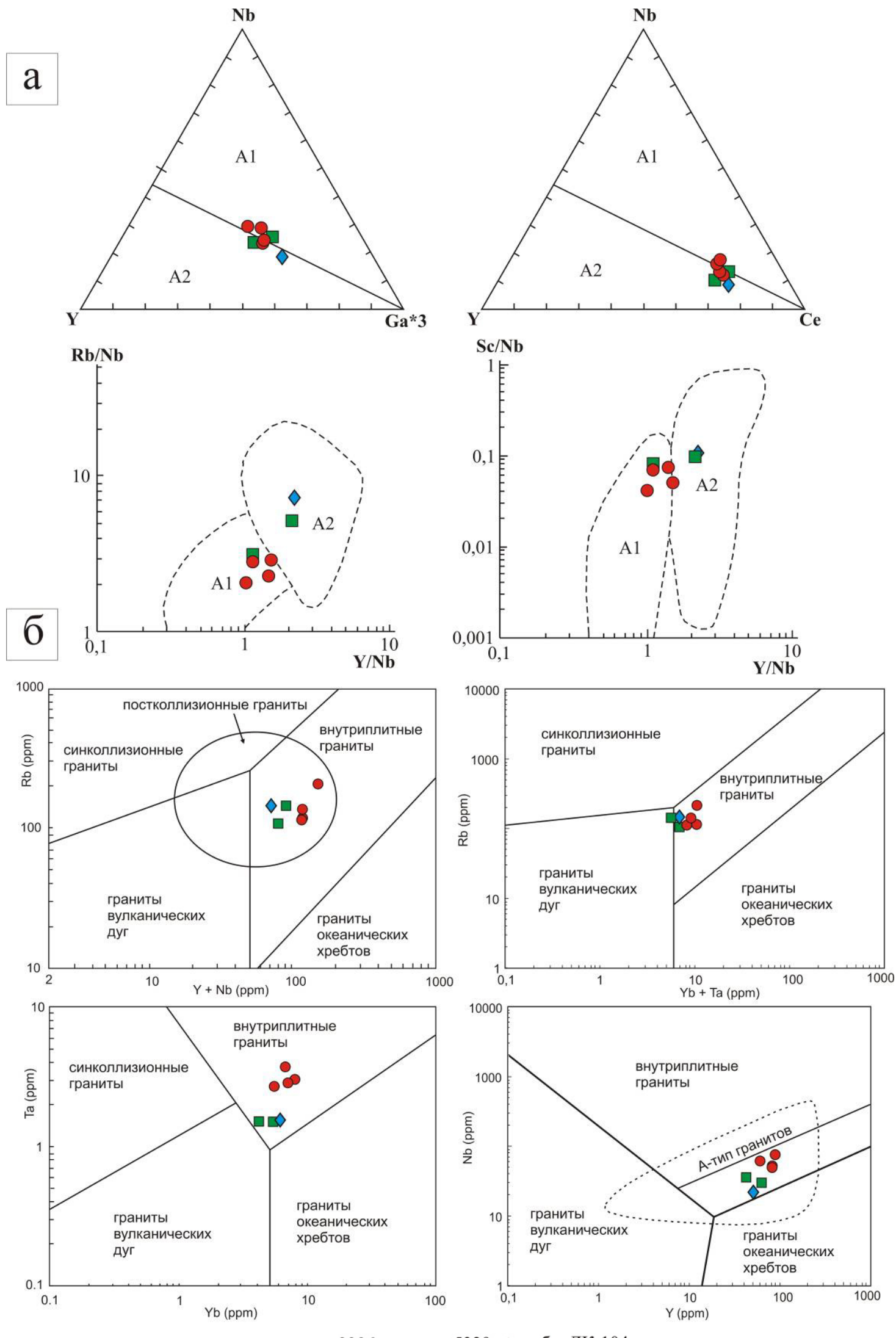

- скв. 2296

- скв. $5329 \diamond$ - обр. ЛК-104

Puc. 8. Составы неоархейских ультракалиевых риолитов лебединской свиты Курского блока: $a$ - на дискриминантных диаграммах по (Eby, 1992) [10]; б - на дискриминантных диаграммах по (Pearce et al., 1984) [11]. Поля гранитоидов А-типа: $A 1$ - кислые магматические породы океанических островов и континентальных рифтов; $A 2$ - анорогенные гранитоиды постколлизионных обстановок (в геодинамических условиях внутри- и окраинно-континентального типов). 
Данные геотектонические условия образования ультракалиевых риолитов лебединской свиты согласуются и с временной позицией геологической истории формирования Курского блока в неоархее. Определенный возраст ультракалиевых риолитов в интервале времени 2612 \pm 10 млн лет [1] свидетельствует об формировании этих пород после образования складчатости, а также фиксирует одновременное проявление кислого внутриплитного вулканизма вместе с гранитоидными интрузиями атаманского комплекса (2528 $\pm 4-2615 \pm 15$ млн лет) [12]. Таким образом, ультракалиевые риолиты появились на завершающем этапе орогенного развития Курского блока в процессе его тектоно-магматической активизации и определили нижнюю границу формирования палеопротерозойских толщ курской серии.

\section{Возможные источники расплавов}

Для оценки возможных источников вулканитов кислого состава были проанализированы Sm-Nd изотопно-геохимические данные. Отрицательные значения $\varepsilon_{\mathrm{Nd}}$ (табл. 3) для кислых вулканитов могут свидетельствовать о том, что их источники имели длительную коровую предысторию $(\mathrm{TNd}(\mathrm{DM})=3300$ млн лет).

Sm-Nd изотопные данные для неоархейских ультракалиевых риолитов лебединской свиты Курского блока

\begin{tabular}{|c|c|c|c|c|c|c|c|}
\hline \multirow{2}{*}{ № обр. } & \multicolumn{2}{|c|}{ Содержание, ppm } & \multirow{2}{*}{${ }^{147} \mathrm{Sm} /{ }^{144} \mathrm{Nd}^{*}$} & \multirow{2}{*}{${ }^{143} \mathrm{Nd} /{ }^{144} \mathrm{Nd}$} & \multirow{2}{*}{$\mathrm{T}^{* *}$} & \multirow{2}{*}{$\varepsilon \mathrm{Nd}_{(\mathrm{T})}$} & \multirow{2}{*}{$\mathrm{T}-\mathrm{DM} * * *$} \\
\hline & Sm мкг/г & $\mathrm{Nd}$ мкг/Г & & & & & \\
\hline ЛК104 & 4,8272 & 25,5434 & 0,11424 & 0,510892 & 2612 & $-6,4$ & 3436 \\
\hline $2296 / 211,5$ & 13,7819 & 77,5896 & 0,10735 & 0,510789 & 2612 & $-6,1$ & 3361 \\
\hline
\end{tabular}

В результате анализа литературных данных были рассмотрены достаточно разнообразные гипотезы образования ультракалиевых риолитов [13, 14, 15], основными из которых являются: 1) магматическая модель формирования, которая представлена как минимум тремя возможными способами обогащения расплава калием - парциальное плавление обогащенного калием кристаллического субстрата земной коры, ликвационное расщепление расплава на натриевую и калиевую фазы и метамагматическая модель, основанная на постепенном обогащении магматического расплава калием (флюидно-магматическое взаимодействие); 2) немагматическая модель формирования предполагает присутствие метасоматических процессов в накоплении калия, или же объясняется низкотемпературной одуляризацией первично стекловатых риолитов.

Согласно экспериментальным данным, возможными коровыми источниками для кислых расплавов А-типа могут быть породы, образующиеся при высокотемпературном частичном плавлении нижне- и среднекоровых пород тоналитового или гранодиоритового состава, на формирование которых могут влиять как температура плавления, так и окислительновосстановительные условия. В качестве подобного корового источника для неоархейских ультракалиевых риолитов лебединской свиты можно рассматривать тоналит-трондьемит-гранодиоритовые гнейсы обоянского комплекса (рис. 9).

Однако остается нерешенным вопрос о привносе в магматический расплав большого количества калия для того, чтобы сформировались расплавы высококалиевого состава. Такие расплавы, возможно, могли возникнуть при парциальном плавлении кристаллического субстрата при последовательном метаморфизме метапелитовых пород [13]. Возможно, формирование ультракалиевых расплавов кислого состава происходило при воздействии на гранитные расплавы потоков калийсодержащих флюидов, что указывает на их связь с мантийными компонентами.

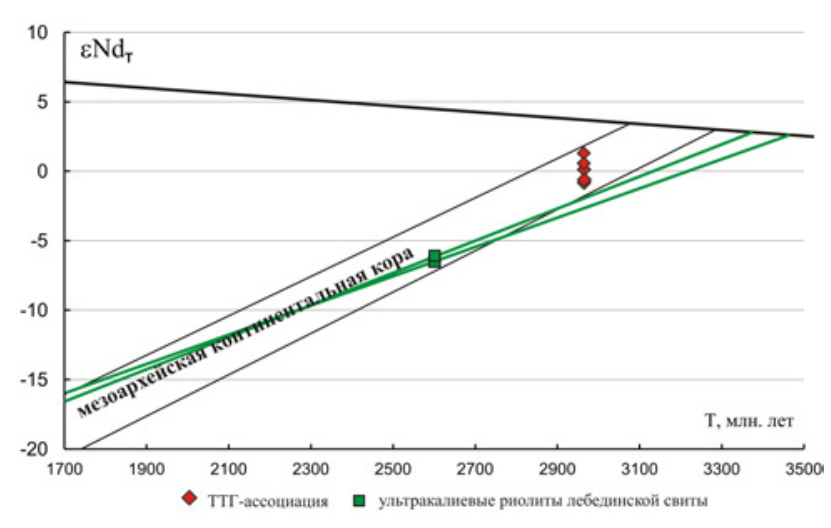

Puc. 9. Диаграмма $\varepsilon \mathrm{Nd}-\mathrm{T}$ для неоархейских ультракалиевых риолитов лебединской свиты Курского блока.

Об участии корового и мантийного компонентов [16] при формировании кислых пород могут свидетельствовать данные по содержанию $\mathrm{Rb}$ и отношения $\mathrm{K} / \mathrm{Rb}$ в риолитах. Положение точек составов пород на диаграмме $\mathrm{K} / \mathrm{Rb}-\mathrm{Rb}$ (рис. 10), на которой выделены области мантийных, коровых и мантийно-коровых гранитоидов [17], свидетельствует об их принадлежности к гибридным образованиям, состоящим из смеси корового и мантийного материала. Следовательно, возможным источником тепла и поставщиком мантийного вещества были базитовые расплавы. Таким образом, коровое вещество доминирует в составе кислых пород, а мантийное вещество является носителем тепловой энергии, за счет которой плавился материал коры, а также служит источником привноса калийсодержащих флюидов.

Предполагается, что процессы формирования риолитового расплава протекали под воздействием глубинных флюидов с низкой активностью $\mathrm{H}_{2} \mathrm{O}$ из высокотемпературных магм (более $1000^{\circ}$ ) при давлении $>8$ кбар (температура кристаллизации риолитов 850$\left.860^{\circ}\right)$ [18]. 


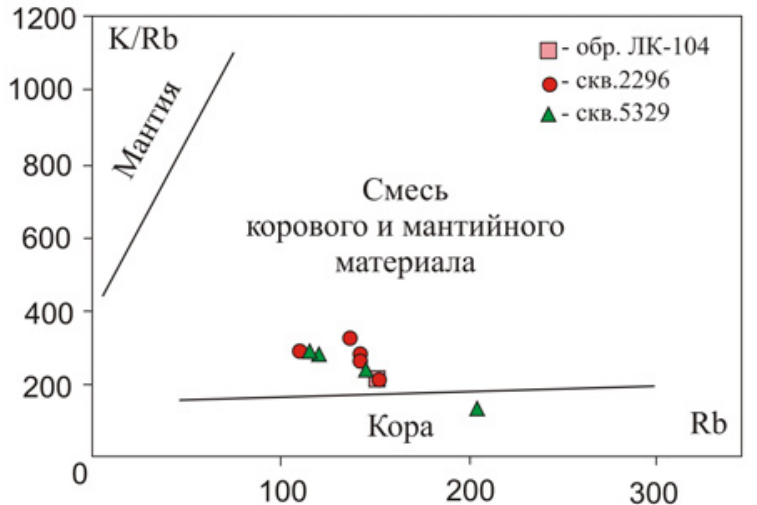

Puc. 10. Диаграмма K/Rb-Rb для ультракалиевых риолитов лебединской свиты Курского блока.

Источником мантийного вещества в пределах Курского блока могут являться неоархейские метабазиты, подстилающие ультракалиевые риолиты (рис. 2).

\section{Выводы}

Проанализировав полученные результаты, можно сделать следующие выводы:

1. По петрогеохимическим характеристикам породы представляют собой недифференцированную серию ультракалиевых риолитов и типичны для магматических пород кислого состава корового происхождения. Что свидетельствует о магматической природе этих пород.

2. Установлено, что по своим геохимическим особенностям ультракалиевые риолиты лебединской свиты относятся к гранитоидам А-типа и сформировались во внутриплитной постколлизионной геодинамической обстановке. Локальное расположение риолитов, незначительный объем и их приуроченность к отдельным структурным зонам Тим-Ястребовской структуры Курского блока указывает на приуроченность данных пород к постколлизионной рифтовой структуре.

3. Формирование ультракалиевых риолитовых расплавов возможно при взаимодействии коровых магм с обогащенным материалом подлитосферной мантии. В качестве возможного корового источника расплава для неоархейских ультракалиевых риолитов могли быть тоналит-трондьемит-гранодиоритовые гнейсы обоянского комплекса, которые взаимодействовали с мантийным веществом, несущим калийсодержащие флюиды при низкой активности $\mathrm{H}_{2} \mathrm{O}$. Источником мантийного вещества в пределах Курского блока могут являться неоархейские метабазиты михайловской серии, подстилающие ультракалиевые риолиты.

\section{ЛИТЕРАТУРА}

1. Возраст неоархейских ультракалиевых риолитов - важный геохронологический репер эволюции раннедокембрийской коры Воронежского кристаллического массива / К. А. Савко [и др.] // Изотопное датирование геологических процессов: новые

Воронежский государственный университет Холина Наталья Викторовна, преподаватель кафедры полезных ископаемых и недропользования, ведущий инженер НИИ Геологии ВГУ

E-mail: holina_geol@mail.ru; Teл.: 8 (473) 222-64-19 результаты, подходы и перспективы. Материалы VI Российской конференции по изотопной геохронологии. - ИГГД РАН Санкт-Петербург. СПб : Sprinter, 2015. - C.247-249.

2. Larionov, A. N. The Vendian alkaline igneous suite of northern Timan: ion microprobe $\mathrm{U}-\mathrm{Pb}$ zircon ages of gabbros and syenite / A.N. Larionov, D.G. Gee, V.L.(Eds.) Pease // Geol. Soc. London Mem. - 2004. - V. 30. - P. 69-74.

3. Steiger, R. H. Subcommission on geochronology: convention of the ust of decay constants in geo- and cosmochronology / R. H. Steiger, E. Jäger // Earth Planet. Sci. Lett. - 1977. - V. 36. - P. 359-362.

4. Stacey, J. S. Approximation of terrestrial lead isotope evolution by a two-stage model / J. S. Stacey, J. D. Kramers // Earth and Planet. Sci. Lett. - 1975. - V. 26. - N. 2. - P. 207-221.

5. Ludwig, K. R. SQUID 1.12 A User's Manual. A Geochronological Toolkit for Microsoft Excel / K. R. Ludwig // Berkeley Geochronology Center Special Publication. - 2005a. - 22 p.

6. Ludwig, $K$. R. User's Manual for ISOPLOT/Ex 3.22. A Geochronological Toolkit for Microsoft Excel / K. R. Ludwig // Berkeley Geochronology Center Special Publication. - 2005b. - 71 p.

7. Maniar, P. D. Tectonic discrimination of granitoids / P. D. Maniar, P.M. Piccoli // Geol. Soc. Amer. Bull. - 1989. - V. 101. — P. 635-643.

8. Harker, A. The Tertiary igneous rocks of skye / A. Harker // Mem. Geol. Surv. - United Kingdom. - 1904. - 481 p.

9. Whalen, J. B. A-type granites: geochemical characteristics discrimination and petrogenesis / J. B. Whalen, K. L. Currie, B. W. Chappell // Contrib. Mineral. Petrol. - 1987. - V. 95. - P. 407-419.

10. Eby, G. N. Chemical subdivision of the A-type granitoids: petrogenetic and tectonic implications / G. N. Eby // Geology. 1992. - V. 20. - P. 641-644.

11. Pearce, J. A. Trace element discrimination diagrams for the tectonic interpretation of granitic rocks / J. A. Pearce, N. B. W. Harris, A. G. Tindle // J. Petrol. - 1984. - V. 25. - P. 956-983.

12. Артеменко, Г. В. Геохронологическая корреляция вулканизма и гранитоидного магматизма юго-восточной части Украинского щита и Курской магнитной аномалии / Г. В. Артеменко // Геохимия и рудообразование. - Киев: Наукова думка, 1995. Вып. 21. - С. 129-154.

13. Фромберг, Э. Д. Ультракалиевые риолиты - геология, геохимия, петрология: Автореф. дис. ...д-ра геолого-минерал. наук: 04.00.08 / Э. Д. Фромберг. Московский гос. ун-т. Москва, 1993. -45 с.

14. Литвиновский, Б. А. Генезис ультракалиевых кварцевых порфиров на севере Арабо-Нубийского щита / Б. А. Литвиновский, Н. С. Карманов, Е. Вапник // Геология и геофизика. 2006. - T.47. - №11. - C.1123-1147.

15. Safonov, $O$. G. Interaction of biotite-amphibole gneiss with $\mathrm{H}_{2} \mathrm{O}-\mathrm{CO}_{2}-(\mathrm{K}, \mathrm{Na}) \mathrm{Cl}$ fluids at $550 \mathrm{MPa}$ and 750 and $800^{\circ} \mathrm{C}$ : experimental study and applications to dehydration and partial melting in the middle crust / O. G. Safonov, S. A. Kosova, Dirk D. van Reenen // Journal of Petrology. - 2014. - V. 55. - N. 12. - P. 2419-2456.

16. Гребенников, А. В. Гранитоиды А-типа: проблемы диагностики, формирования и систематики / А. В. Гребенников // Геология и геофизика. - 2014. - Т. 55. - № 9. - С. 1356-1373.

17. Коваленко, В. И. Вариации коэффициента распределения рубидия в магматических породах / В. И. Коваленко, В. С. Антипин, И. Д. Рябчиков // Геохимия. - 1981. - № 7. - С. 1017-1029.

18. Холина, Н. В. Высокие температуры кристаллизации неоархейских риолитов Курского блока Воронежского кристаллического массива: результаты минеральной термометрии / Н. В. Холина, К. А. Савко, В. М. Холин // Вестн. Воронеж. гос. ун-та. Сер. : Геология. - 2016. - №3. - С. 53-60.

Voronezh State University

Holina N. V., Lecturer of the Mineral Resource Department, the Master Engineer of SRI of Geology

E-mail: holina_geol@mail.ru

Tel.: 8 (473) 222-64-19 